\title{
La reina Leonor de Chipre y los Catalanes de su entorno
}

\author{
Maria Teresa FerRer I MALLOL
}

\section{UNA REINA CATALANA EN CHIPREI}

En 1353 salía de Barcelona hacia Chipre una princesa de la dinastía barcelonesa, reinante en la Corona de Aragón, para casarse con el príncipe heredero de dicha isla, Pedro de Lusignan, conde de Trípoli ${ }^{2}$. La novia era Leonor de Prades, hija del infante Pedro, conde de Ribagorza y Prades, nieta del rey Jaime II y prima hermana del monarca entonces reinante, Pedro el Ceremonioso. Llegó a Barcelona el 1 de febrero de 1353, pero no se embarcó hasta el 21 de agosto de 1353 en una coca de tres cubiertas, conocida como la de la sociedad de los mercaderes de Barcelona ${ }^{3}$. Era época de guerra con Génova, pero la flota catalana, al mando de Bernat de Cabrera, había zarpado poco antes de Menorca y se encontraba ya en los alrededores de Cerdeña, donde después de reunirse con una flota veneciana derrotaron juntas la flota genovesa. El mar, pues, debía considerarse seguro para csa nave y no consta que llevara acompañamiento de otras. Sólo un año después, sin embargo, la situación había cambiado de signo y esa misma coca que había llevado a Leonor a Chipre tuvo que ser quemada en la playa barcclonesa para evitar que una flota genovesa que se presentó ante la ciudad se apoderara de ella ${ }^{4}$.

Leonor se desplazó, pues, a Chipre con una nave comercial y desde entonces se relacionó mucho con los mercaderes y patrones de nave barceloneses, puesto que, de sus compatriotas, eran los únicos que visitaban la isla con regularidad. La política papal de prohibición de las relaciones comerciales con los mamelucos del sultanato de Babilonia había provocado el crecimiento económico de Chipre aunque, como señala M. Balard, la concesión de licencias para comerciar con el sultanato por el Papado, desde mediados del siglo xIv, tendió a disminuir esa importancia ${ }^{5}$.

1. Es una satisfacción para mi poder dedicar este trabajo al Profol. Michel Balard, que ha contribuido de manera decisiva al mejor conocimiento del Oriente cristiano mediterráneo.

2. Este trabajo forma parte del proyecto de investigación La Corona de Aragón potencia mediterránea: expansión territorial y económica en la Baja Edad Media, concedido por la CICYT (BHA2001-0192). Se beneficia también de la ayuda otorgada al "grup de recerca consolidat La Corona catalanoaragonesa, l'Islam i el món mediserrani", por el Departament d'Universitats, Recerca i Societat de la informació, para el periodo 2001-2004.

3. Crònica del racional de la ciutat (1334-1417), ed. P. Pujol I TuBAu, Barcelona 1921 (Recull de Documents i Estudis 1, fasc. 2), p. 16-17.

4. Ibid., p. 123-124. Sobre la guerra cf. G. Meloni, Genova e Aragona all'epoca di Pietro il Cerimonioso, 3 vol., Padova 1971-1982. Sobre el reinado de Leonor en Chipre cf. L. DE MAS l.ATRIE, Histoire de l'ile de Chypre sous le règne des princes de la maison de Lusignan, 3 vol., París 1852-1861. G. Hu.L, A History of Cyprus, vol. 2 y 3, Cambridge 1948. Cf. también LA. Nicolali i"Olwer, L'expansió de Catalunya en la Mediterrània oriental, Barcelona 19743', p. 128-136. obra que, aunque antigua, es un buen resumen que conecta con la historia catalana.

5. M. BALARD. Chypre, les républiques maritimes italiennes et les plans de croisade (1274-1370), 
A la dificultad de tener que obtener una licencia se añadía, para los mercaderes catalanes, las restricciones impuestas a la movilidad de la flota comercial, especialmente en los viajes a larga distancia, a causa de la guerra con Génova ${ }^{6}$. El viaje de la infanta a Chipre debió ser una buena oportunidad para muchos de ellos. Por ejemplo, el mercader barcelonés Guillem Torroja, que viajaba en esa coca, aprovechó la ocasión para solicitar permiso para trasladarse después a Beirut; meses antes, el rey también había autorizado la saca de caballos hacia Chipre, tanto por parte de los embajadores que habían de acompañar a la infanta como de otras personas?

No me detendré a comentar los acontecimientos del reinado de Pedro I, el esposo de Leonor, ni su asesinato, en 1369, ni tampoco la venganza de la reina, que ordenó asesinar a su cuñado, el príncipe de Antioquía, culpable de aquel asesinato, puesto que son muy $\operatorname{conocidos}^{8}$. Mi artículo tiene el objetivo de aportar noticias procedentes de la documentación catalana que iluminan algunos aspectos de la vida de esta mujer apasionada y orgullosa, especialmente su desgraciada expulsión de Chipre.

Después de la muerte de su esposo, tenemos constancia de numerosas embajadas entre la corte catalano-aragonesa y Chipre. En el mismo año 1369, Pedro el Ceremonioso envió a sus consejeros Jaume Fiveller y Francesc de Vilarrasa a la reina para manifestarle su condolencia por la muerte de su esposo 9 .

De estos dos consejeros, Jaume Fiveller continuaría ocupándose con frecuencia de los asuntos de la reina de Chipre. En esa misión de mantener el contacto de la reina con la corte catalana destacó también Lleó Marc o March, hermano de Jaume y Pere, ambos poctas, y tío de Ausiàs March, el más famoso de los poetas de la literatura medieval catalana. A Lleó Marc le encontramos realizando servicios a la reina, al menos desde 1372 , llevando regalos y cartas entre ambas cortes; aunque la vida de Leonor, después de la muerte de su esposo, continuaba siendo tormentosa, ahora a causa de las tensiones entre su propio partido y el de los nobles, sin embargo, la reina encontraba momentos de placidez para escoger y enviar regalos a sus regios parientes de la Corona de Aragón, como veremos más adelante.

Sabemos que de regreso de otro de los viajes de Lleó Marc a Chipre, en 1374, llevó cartas y regalos para el rey Pedro el Ceremonioso. En su respuesta, este monarca se sorprendía de no haber sido informado ni por su prima, la reina de Chipre, ni por el rey su hijo de los graves disturbios en la isla, de los que había tenido noticias a través de los genoveses ${ }^{10}$.

Cyprus and the Crusades. Papers given at the International Conference (Nicosia 6-9 september 1994), ed. N. Colreas, J. Riley-Smith, Nicosia 1995, p. 97-106, concretamente, p. 104.

6. M. T. Ferrer i Mal.1.01. Jurisdicció i control de la navegació a la ribera i mar de Barcelona, Anales de la Universidad de Alicante, H. Historia Medieval 12, 1999, p. 113-133.

7. ACA, C, reg. 895 , fol. 79v. (1352, septiembre, 28 ) y reg. 896. fol. $80 \mathrm{r}$. (1353, agosto, 6).

8. Además de las historias de Chipre ya citadas cf. J. RICHARD, La révolution de 1369 dans le royaume de Chypre, Bibliotheque de l'École des Chartes 110, 1952, p. 108-123. P. W. F.DBury, The crusading policy of King Peter I of Cyprus, 1359-1369. The Eastern Mediterranean lands in the period of the Crusades, ed. P. M. Hoir, Warminster 1977, p. 90-105 (= Kingdoms of the Crusaders. From Jerusalem to Cyprus, Aldershot 1999. XII): ID.. The murder of King Peter I of Cyprus (1359-1369), Journal of Medieval History 6, 1980, p. 219-233 (= Kingdoms of the Crusaders, op. cit.. XIII).

9. Jerónimo ZurJTA, Anales de la Corona de Aragón, ed. Á. CANELlas LóPEZ, Zaragoza 1967-1986, 3, p. $600-601$.

10. ACA, C, reg. 1091, fol. 7r.-v. (1374, junio, 13). 


\section{LOS REGALOS ENTRE RLYES}

Era costumbre entre reyes, especialmente entre los que eran parientes, remitirse regalos valiosos y también que se solicitasen objetos o animales preciados que se encontraban en el país de otro monarca. Una carta de la reina Leonor de Sicilia, esposa de Pedro el Ceremonioso, a Leonor de Chipre, de 1372, nos muestra cómo eran esos regalos. La reina acusaba recibo de los que le habían sido remitidos por medio del mercader barcelonés Lleó Marc desde Chipre. Los regalos, que complacieron mucho a la reina, eran productos de perfumería, como nueve barrals domesquins d'aigua ros, es decir garrafas de agua de rosas, diez vejigas de almizcle, una cepa de linyaloe, es decir, lignum aloe y una banya de civeta, además de una caja llena de pajaritos. Es posible que los pajaritos fueran pájaros tropicales procedentes de África. como los leopardos, que también eran solicitados a Chipre'l. La reina Leonor de Sicilia había pensado corresponder con el envío de mulas, pero una conversación con Luis Resta, mensajero de la reina de Chipre, la disuadió de enviar ese regalo. No consta qué regalos envió finalmente, aunque sí le mandó una larga lista de productos que deseaba: telas preciosas - seis piezas de atzeituní, dos de las cuales tenadas o moradas y otras dos carmesíes, dos piezas de xamellot o camelot de lana fina, doce pares de xamellots mercaders, de diversos colores, tres o cuatro libras de seda carmesina torcida y una libra de seda igual, pero sin torcer, floja; tres piezas de damasco estrecho, con la señal del rey y otras tres con la señal de la reina - mazas de Damasco a la moda, seis bacinets o pequeños cuencos para poner perlas, dos bacins grandes, o palanganas, para lavarse la cabeza y un conjunto de bacins planos, es decir, bandejas. La lista y la carta, en la que, además, la reina informaba del buen estado de salud de su familia, fue confiada, de nuevo, al mismo Lleó Marc, que reemprendía viaje hacia Chipre y que dcbía comentar a la reina de Chipre algo a propósito de los pájaros, del almizcle y del ámbar; además, había de interesarse por si la rcina conocía alguna esclava que supiera coser seda, oro y fres, es decir, pasamanos; si él mismo encontraba una esclava apropiada debía comprarla ${ }^{12}$. Las aplicaciones de oro en las telas de lujo exigían una técnica especial, que todavía se practica en los bordados de los mantos de las imágenes llevadas en procesión en Murcia y en Andalucía.

A la vuelta de otro de sus viajes a Chipre, en 1374, Lleó Marc llevó al rey Pedro el Ceremonioso un pabellón de parte de su prima ${ }^{13}$; tiendas y pabellones eran necesarios para las campañas de guerra o para fiestas y los monarcas solían apreciar los que eran lujosos, como debía ser el caso.

También Ramon de Perellós, vizconde de Roda, trajo regalos para el infante primogénito Juan a la vuelta de su viaje a Chipre, a principios del año 1378 . Entre los regalos enviados por la reina figuraban un libro de fra Odorico de Podernone, que según Rubió debía ser De mirabilibus Terre Sancte, un sombrero turco y un arco también turco; los regalos enviados por el rey de Chipre no se detallan ${ }^{14}$.

11. Juan I pidió insistertemente al rey de Chipre leopardos para cazar: ACA, C. reg. 1961r.-v. (1391 . diciembre, 3), reg. 1963, fol. 142r. (1392, agosto. 28), reg. 1968, fol. 3v. (1394, dicicmbre. 9), etc.

12. ACA, C, reg. 1582, fol. 42v. (1372, diciembre, 12)

13. ACA, C, reg. 1091, fol. 7r.-v. (1374, junio, 13).

14. A. Rubió Y LLuCH, Documents per l'història de la cultura catulana mig-eval. Barcelona 2000 (edición facsímil de la de 1908-1921): 1, docs. 293 y 296, p. 273 y $274-275$. 
En 1378, fue otro de los barceloneses que se relacionaban con la corte chipriota, Joan Desbosc, quien se encargó de llevar a Pedro el Ceremonioso el regalo que el rey de Chipre le enviaba como muestra de agradecimiento por la flota enviada para acompañar a Valentina Visconti y por la ayuda prestada en el intento de recuperar Famagusta. El regalo era una reliquia del brazo de san Jorge, engastada en un brazo y mano de plata, regalo que fue extremadamente apreciado ${ }^{15}$. En Barcelona se celebró una procesión, con el brazo, el 23 de abril de 1378 , con los canónigos y clérigos de la catedral, el clero de las parroquias y los religiosos de la ciudad ${ }^{16}$. El mismo Joan Desbosc, que había traído la preciada reliquia, fue nuevamente el encargado de llevar las cartas y un regalo del Ceremonioso para la reina Leonor de Chipre, consistente en una tela escarlata y nada menos que mil dorsos de vais o veros, que solían usarse para forros de piezas de vestir, con los que el rey quiso corresponder al espléndido regalo recibido 17 .

Cuando la reina ya había tenido que exiliarse, todavia el batliu o administrador de sus bienes en Chipre, Tomás Arcigilacha (Khartophylaka) - otras veces aparece citado como Arcofileta - envió al rey Pedro el Ceremonioso dos medias botas de vino fino marna, por medio de la nave de Francesc Casasaja, en junio de 1383; el rey se apresuró a solicitar a su lugarteniente de maestro racional, Bernat Descoll, que recogiera esas botas y las guardara en su casa, a fin de que el vino no se estropearat8.

\section{LA AYUdA CAIALANA CONTRA LA OCLPACIÓN GENOVESA DE FAMAGIISTA Y LA FI.OTA} PaRA ACOMPañar VAI.ENTINA Visconti A CHIPRE

Los disturbios internos que se habían registrado en Chipre entre 1373 y 1374 habían llevado a una situación crítica; la reina reclamó la ayuda de los genoveses, que tenían en la isla una colonia numerosa y muchos intereses comerciales. El resultado de esa intervención fue la ocupación de Famagusta por Génova, que ya no se retiró ${ }^{19}$.

El monarca chipriota se propuso recuperar Famagusta y para ello buscó ayuda en Venecia y en la Corona de Aragón. Un mensajero de la reina de Chipre, Alfons Ferran, fue enviado a Cataluña, en 1378, para buscar gente de armas que quisiese pasar a la isla tomando su sueldo, aunque el dinero que el mensajero llevaba no alcanzó para tanto y acabó en la cárcel. El noble Guerau de Queralt prometió ir con 250 lanzas y con una galera, que comenzó a armar en enero y que salió con destino a Chipre hacia el mes de mayo; Ramón de Perellós, que había hecho un viaje a Chipre en 1377, también consiguió permiso del rey para ir con cien lanzas, en compañía de seu hermano Francesc y otros nobles amigos; no salió, sin embargo, con Guerau de Queralt y fue retrasando su viaje, aunque continuó preparándolo, como lo prueba los pagos que le hicieron los representantes de la reina Leonor en

15. ACA. C. reg. 1263 , fol. 46r. (1378, noviembre, 13).

16. Crònica del racional de la ciufat, citada supra n. 3, p. 153.

17. ACA, C. reg. 1263, fol. 46r. (1378, noviembre, 13).

18. ACA, C, reg. 1282, fol. 85v. (1383, junio, 13).

19. Cf. sobre la intervención genovesa en Chipre: MELon]. Genova e Aragona, citado supra n, 4, 3. p. 112-119, 122-125, 130-131. Cf. también P. W. EDBuRY, Cyprus and Genoa: the origins of the war of

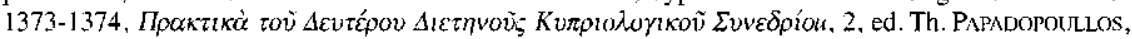
B. EGGLFZAKËS, Nicosia 1986, p. 108-126 (= Kingdoms of the Crusaders, citado supra n. 8, XIV). 
Barcelona, que eran, precisamente, Lleó Marc y Joan Desbosc, otro patrón de nave barcelonés, quienes usaron dinero o mercancías, probablemente azúcar, que habían recibido del rey de Chipre ${ }^{20}$; esos pagos fueron restituidos después, cuando el vizconde abandonó el viaje; no parece que hubiera hecho lo mismo con respecto a Venecia, que en 1380 se quejó a Pedro el Cerimonioso por el incumplimiento del servicio contra los genoveses, al que el vizconde se había comprometido, y reclamó la devolución del anticipo de 2.400 ducados que el vizconde había recibido por dos meses de servicio. Suponemos que al vizconde también le resultaba difícil recuperar los anticipos que él mismo había concedido a los que le habían de acompañar.

También en ese mismo año 1378, en enero, habían llegado a Barcelona unos embajadores del rey Pedro de Chipre: Ramón Robert, arcediano de Famagusta y electo de Pafos, Luis Resta y Ramón Resta. Este último había pasado previamente por Milán y había recibido, parece, el encargo de organizar en Cataluña una pequeña flota para acompañar a Chipre a Valentina Visconti, hija de Bernabò, vicario imperial y scñor de la ciudad de Milán, que se casaba con Pedro II. Ramón Resta llevaba poderes del señor de Milán para tomar un préstamo de hasta 8.000 florines de oro de Florencia, que él se comprometía a pagar en Milán ${ }^{21}$. Pocos días después, el 17 de enero, se puso la bandera ante el pórtico de Mar de Barcelona, para enrolar gente para esta armada22. Por los poderes de Ramón Resta a sus compañeros de embajada, cuando en febrero de ese mismo año tuvo que irse a Milán, sabemos que acompañaban a Jos embajadores Francisco Resta, Ramón de Maiolano, rector de la iglesia mayor del cementerio de Nicosia, y Étienne de Lunel, de la diócesis francesa de Tours, todos los cuales firmaron como testigos, además de Jaume Fiveller y un notario ${ }^{23}$. De los embajadores, sabemos que al menos Ramón Robert. electo de Pafos, continuaba en Barcelona a fïnes de abril de 1378, trabajando en la preparación de la flota, con la que debió partir en mayo hacia Chipre; tanto él mismo como Luis Resta tomaron en préstamo de Francesc de Casásaja, mercader y patrón de nave barcelonés, una buena parte del dincro que se usó para cl armamento, además del dincro y mercancías que Joan Desbosc había traido de Chipre ${ }^{24}$.

Sc aprontó, efectivamente, una pequeña flota de seis galeras que, bajo la capitanía de Hug de Santa Pau, se encargó, en mayo, de llevar a Valentina Visconti a la isla, junto con una flota similar veneciana, con la misión de ayudar, además, al rey de Chipre contra sus encmigos, lo que significaba, evidentemente, atacar a los genoveses. Quizás estos movimientos predispusicron a Génova a facilitar las negociaciones de paz con la Corona catalano-aragonesa ya que en el fondo ninguna de

20. Consta que Joan Desbosc era patrón de nave en AHPB, 23-4 (Francesc de I adernosa, manual 14), fol. 13r. (1378. abril, 22). En fol. 14v.-15r., 17v.-18r. del mismo manual consta que ambos patrones tenían dinero o mercancías del rey de Chipre.

21. M.T. Fkerré I Maliol, Noves dades per a la biografia de Ramon de Perellós, autor del Viátge al Purgatori de Sant Patrici, Miscellània en honor del doctor Casinir Martí, coord. J, M. SAvs, Barcelona 1994, p. 215-230, cuncretamente, p. 223-226.

22. Crònica del Racional de la ciutat, p. 152.

23. AHPB, 23-4 (Francesc de Ladernosa, manual 14), fol. 10v--1 Ir. (1378, febrer. 10). La noticia de que Ramón Resta iba a Milán consta en cl salvoconducto que le otorgó el rey: ACA, C. reg. 1262, fol. 18r. (1378. febrero, 10).

24. El obispo aparece como testigo en la procuración del vizconde de Roda a Jaume de Vallseca para rccuperar el anticipo que había recibido de Jaume Fiveller y de Lleó Marć y que también él habia anticipado a los que habian de acompañarle: AHPB, 23-4 (Francesc de ladernosa, manual 14), fol. 13v. (1378, abril, 24). Sobre los préstamos otorgados por Casasaja: ibid., fol. 47v-48r. (1379, dicjembrc, 12). 
las dos partes deseaba la guerra; por ello el rey ordenó a Hug de Santa Pau y a Guerau de Queralt que no atacasen a los genoveses; esa misma orden debió retener al vizconde, que en julio todavía pagaba los sueldos de ballesteros, marineros y tripulantes en general de la nave del rey de Chipre, patroneada por Jaume Ramon, de Narbona, con la que había de pasar a la isla25; pocos meses después, en octubre de 1378 , Pedro el Ceremonioso ratificaba el tratado de paz con Génova ${ }^{26}$. Tranquilizó, sin embargo, a sus parientes de Chipre, asegurando que la paz no se volvería contra ellos y ofreciéndose a mediar con Génova para conseguir la paz en la isla27. Quizás ese fracaso político de la corte chipriota, que deseaba utilizar Venecia y la Corona catalano-aragonesa para expulsar a los genoveses de Famagusta, puede explicar en parte las represalias tomadas contra los embajadores Ramón y Luis Resta, familiares y domésticos del rey de Chipre, que fucron encarcelados en la isla, aunque también cabe la posibilidad de que hubieran sido acusados de algún desvío del dinero de las ayudas de Milán que manejaron; a su favor intervino el rey Pedro el Ceremonioso que creía que habían servido bien al monarca chipriota y que las malas informaciones que le habían llegado sobre ellos eran falsas ${ }^{28}$.

La paz con Génova no fue efectiva de inmediato. En enero de 1379, los genoveses se quejaron de los ataques que habían recibido en Famagusta tanto de Hug de Santa Pau como de Guerau de Queralt, que continuó en la isla atacándoles con una galera y una galeota, seguramente después de firmada la paz, mientras que en las cercanías de Sicilia también les atacaban el corsario mallorquín Pere Bernat con su galera y una galera valenciana; los genoveses denunciaron igualmente las intenciones del vizconde de Roda, que suponían se preparaba también para atacarles, aunque ya sabemos que en aquellos días había renunciado a pasar a Chipre ${ }^{29}$.

Guerau de Queralt había vuelto ya el 30 de marzo de 1379, pero no fue a desarmar a Barcelona, como hubiera sido natural, puesto que allí se encontraba el rey y allí había de devolver la galera que había usado a la Generalitat de Cataluña, sino que se dirigió a Salou, de donde algunos marineros hubieron de traerla a Barcelona, cosa que costó a la Generalitat más de 36 libras. La razón del desvío de Guerau de Queralt era porque no se atrevía a presentarse en la corte sin salvaguarda, ya que había atacado a los genoveses en Chipre, aunque él aseguraba no haberse extralimitado de la licencia real que había recibido. El rey no quiso darle esa salvaguarda porque temía romper la paz con Génova, mientras que Guerau de Queralt aseguraba haber hecho un gran servicio en Sicilia, que había de explicar personalmente al rey y al primogénito tal como lo había prometido a los barones sicilianos. Ni aún así consiguió la salvaguarda puesto que el rcy le aconsejó que escribiera el mensaje de los barones en una hoja y que lo entregara cerrado y sellado a un mensajero, del que podía tomar juramento y homenaje de no librarlo sino al rey ${ }^{30}$.

25. FirRfir i MAI.J.O., Noves dades per a la biografia de Ramon de Perellós, citado supra n. 21 . p. 223226. AIIPB, 23-4 (Francesc de Ladernosa, manual 14), fol. 20r. (1378, julio, 7).

26. Liber Jurium Reipublicae Genuensis, 2, en Historiate Patriae Monumenta 7. Turín 1857, col. 839-850. Meloni. Genova e Aragona, 3, p. 126-128 y 130-131.

27. Ferrer i Maj, ol. Noves dades per a la biografia de Ramon de Perellós, p. 226.

28. ACA, C. reg. 1265, fol. 56v. (1379, octubrc, 31).

29. Ferrer i Malion , Noves dades per a la biografia de Ramon de Perellós, p. 225.

30. ACA, C, reg. 1263, fol. 126v. (1379, mar7o, 30). AHPB, 23-4 (Francesc de Ladernosa, manual 14), fol. 35r.-v. (1379, abril, 6). Las crónicas de Chipre distorsionan completamente el nombre de Guerau de Queralt y lo convierten en Guy de Gounal, difícilmente reconocible: Hit.., A History of Cyprus, citado supra n. 4,2, p. 424. 
En cuanto a Hug de Santa Pau, volvió en junio de 1379; el rey Pedro el Ceremonioso comunicó la noticia al rey de Chipre, al tiempo que lc expresaba su pesar por el hecho que no se hubiera conseguido la recuperación de Famagusta y le informaba de que había escrito a Génova ofreciéndose a mediar en la cuestión. Parece que tres de las galeras de la flota capitaneada por Hug de Santa Pau pertenecían al rey de Chipre, puesto que en esta misma carta Pedro el Ceremonioso informaba al monarca chipriota que había tenido que venderlas para poder pagar a los galeotes y socios, que exigían su salario, y que le enviaba el proceso que se había seguido en esta cuestión. Añadía que, si necesitaba las galeras, haría todo cuanto estuvicra en su mano por recuperarlas 31 . Hug de Santa Pau había recibido en premio a su ayuda el casal de Quiados (Kiados) y otras cosas, de muchas de las cuales no había recibido posesión, por lo que no pasaban de ser regalos nominales. Pedro el Ceremonioso reconvino al monarca chipriota por esa actitud y le recordó que las donaciones que hacían los príncipes a sus servidores habían de ser realidad y ser duraderas; por ello le exhortó a dar posesión a su camarlengo Hug de Santa Pau de los bienes que le había concedido ${ }^{32}$. Más adelante, en agosto de 1380 . el rey supo que el casal de Quiados tenía muchas cargas: el abad de Belloc lo tenía per apaut mientras que una dama llamada Blanca tenía una concesión de 1500 besantes sobre las rentas del casal y un clérigo, cuyo nombre no es indicado, tenía otros 200. Otro casal concedido a Hug de Santa Pau era el de Singrasi (Sygkrasis), sobre el que un predicador recibía 500 besantes. En su carta al monarca chipriota, Pedro el Ceremonioso aseguraba que csos casales tenían tantas cargas que apenas reportaban ningún provecho al concesionario y le rogó, por tanto, que los liberase de esas cargas, en consideración a los servicios prestados por dicho noble; sólo entonces el donativo hecho sería cumplido. También le solicitó la donación al mismo Hug de Santa Pau de cinco o seis siervos que se encontraban en el casal de Quiados y que no habían sido incluidos en la donación 33 .

\section{EL PROCESO Y LA EXPULSIÓN DL LA REINA MADRL}

Las luchas intestinas en Chipre habían desembocado en la ocupación de Famagusta por los genoveses y el rey y la corte pudieron comprobar con rabia, impotencia y desaliento que no podían dar la vuelta a esa situación; alguien había de cargar con la culpa del desastre sufrido y la reina madre fuc la persona escogida; sus desavenencias con el hijo y con la nuera la dejaron desprotegida y su posición se fue debilitando; su familia de origen estaba lejos y no se temía su intervención armada a favor de la reina. En diciembre de 1379 cundió la alarma entre sus parientes porque llegó la noticia de que el rey de Chipre tenía presa a su madre en un castillo. Su hermano, cl obispo de Valencia, Jaume d'Aragó, se trasladó a Barcelona para deliberar qué hacer junto con los servidores y amigos de la reina, que se encontraban al lado del infante Pedro, su padre, mientras que Alfons, marqués de Villena, y Joan, conde de Prades, los otros dos hermanos, que se hallaban en la corte castellana, hicicron llcgar su consejo por carta. Se decidió enviar a Chipre a Jaume Fiveller con el fin de obtener su liberación; Fiveller parecía la persona indi-

31. ACA, C, reg. 1263. lol. 1644.-165r. (1379, junio, 20).

32. ACA, C, reg. 1265, fol. 58v.-59r. (1379, noviembre, 5).

33. ACA, C. reg. 1268, fol. 102v.-104v. (1380, agosto, 25 y septiembre, 1). El rey escribió sobre cl mismo asunto a Jean de Brie, turcopolier de Chipre: $i b i d$. 
cada por su conocimiento de la corte de Chipre y su experiencia en embajadas. De acuerdo con Lleó Marc, que como él era procurador de la reina en Cataluña, retuvo de los bienes de ésta 250 tlorines de oro para pagar los gastos del viaje ${ }^{34}$. Si se llevó a cabo ese viaje, no se consiguió más que alargar algo más la crisis.

La reina fue sometida a proceso y fue expulsada de la isla. Según G. Hill, la expulsión se debió a las constantes fricciones entre la reina madre y la nueva reina, que aconsejó a su marido, un joven de caràcter débil, alejarla y enviarla a su patria; pero como vemos, esa expulsión se revistió de ropaje jurídico, basándose seguramente en la acusación de que la reina se había puesto en contacto con los genoveses a fin de entregarles la isla, acusación que carece de fundamento documentado; tampoco merecen mayor crédito las historias de amantes y de vida licenciosa ${ }^{35}$. Desconocemos el momento exacto de su expulsión. Según la crónica chipriota de Strambaldi, la reina había salido de Cerines en octubre de $1380^{36}$, pero esa noticia queda desmentida por los documentos que he reunido, que demuestran que ocurrió unos cuantos meses antes; seguiré, pues, la documentación y no las crónicas, que además de no estar exactamente informadas, reflejan sólo la versión de sus enemigos.

El proceso a que fue sometida la reina tuvo como primera consecuencia la retención de sus rentas. En marzo, Pedro el Ceremonioso y Bernabò Visconti mantenían correspondencia sobre las rentas de la reina, que su hijo no le libraba, y el Ceremonioso solicitaba la intervención del Visconti para que el monarca chipriota entregara a la reina lo que debía, prueba de la influencia de la joven reina en este asunto ${ }^{37}$. Después se produjo el segundo paso: la expulsión de la reina madre. El 8 de abril, esa decisión ya había sido tomada, pero aún no debía haber salido de Chipre. En esa fecha, Pedro el Ceremonioso escribió al dux de Génova para informarle de que dos galeras catalanas irían a recoger a la reina, que volvía a su patria de origen. Le pidió que no se infiriesen daños a las galeras que iban en su busca, ni a ella misma ni a sus bienes, bienes que habrían de venir con otras naves, para las cuales también solicitaba respeto. Comentaba que Leonor tenía casales, rentas y bienes en la isla y que una persona nombrada por la reina se encargaría de administrarlos ${ }^{38}$. El 15 de julio fueron expedidas credenciales a favor de Jaume Fjveller dirigidas al rey de Chipre, a la reina y a Jean de Brie, puesto que era quien tenía que encargarse de recoger a la reina. Todavía el 19 de julio el rey recomendaba a Joan Desbosc, que era doméstico del rey de Chipre, para quien pedía una remuneración por los grandes servicios que había prestado a la corona chipriota, por cuyos intereses velaba siempre en sus reinos; a la reina de Chipre, su esposa, le dirigía una carta de salute y le recomendaba a fra Bernat de Vilagut, de casa de su propia esposa, la reina Sibil.la. de quien era pariente, que iba en peregrinación al Santo Sepulcro ${ }^{39}$. No parece que ninguna de esas cartas hubiera sido escrita en ese tono si la noticia de la humillante expulsión de la reina hubiese llegado a Barcelonid.

34. AIPB, 23-4 (Francesc de Ladernosa, manukl 24), fol. 47r.-v. (1379, diciembre, 13).

35. Hill, A History of Cyprus, 2, p. 425.

36. Cr. el fragmento reproducido por MAS LAIRll, Histoire de l'île de Chypre, citado supra n. 4,3 , p. 761 , nota.

37. ACA, C, reg. 1265, fol. 155v. (1380, marzo, 3).

38. ACA, C, reg. 1268, fol. 2v.-3r. (1380, abril, 8). Fl rey escribió en el mismo sentido a Damiano Cataneo, doctor en leyes, y a Luchino Scarampi. los conservadores de la paz nombrados en el tratado de paz con Génova.

39. ACA, C, reg. 1268, fol. 71 r., 75v.-76r. (1380, julio, 15 y 19). 
No tenemos la certeza de que se conociera esa noticia hasta el 23 de julio, por lo que supongo que debió producirse entre fines de junio y principios de julio de 1380, cuando fue escrito el memorial de lo que Jaume Fiveller, el especialista en los asuntos chipriotas, había de exponer a la reina viuda y a su hijo. Se sabía que la reina viuda se encontraba en Rodas, por lo que el embajador se había de dirigir primero a esta isla. Había de saludar a la reina de parte de toda la familia y había de informarla de que todos sentían mucho la falta de su hijo contra ella y que deseaban que volviera. Le había de comunicar que el rey había mandado mensajería al rey de Chipre informándole de que dos galeras armadas iban a ir a buscarla, pero que se había modificado ese propósito y se le enviaba la nave, con la cual iba el mensajcro. Esa variación, supongo, se debía al cambio de circunstancias; mientras que, si había que recoger a la reina en Chipre, era conveniente hacer una cierta demostración de fuerza, ese requisito ya no era necesario encontrándose la reina en Rodas. La reina había de informar al mensajero de los casales que tenía, de sus rentas y de sus deudas y de todo lo que le debía su hijo u otras personas; también le había de solicitar información del proceso que se había hecho en su contra. Oida esa información y los consejos que la reina quisiera darle, el embajador había de dirigirse a Chipre. Allí debía hacer lo posible para que el rey anulara cl proceso hecho contra su madre y le devolviera la fama y el honor; habría de exigir también que se le devolvieran sus casales y rentas y que se le pagase a él todo lo que se debiera a la reina Leonor. La esposa de Pedro II había de ser requerida para que instara a su marido a corregir todo lo que había hecho malament contra la dita mare sua y para devolverle sus bienes. El embajador había de entrevistarse también con el turcopolier Jean de Brie y otras personas que le pareciera conveniente para conseguir que el rey tratara bien a su madre 40 .

El rey Pedro cl Ceremonioso autorizó a Fiveller, a primeros de septiembre de ese mismo año, a sacar del reino 2.000 ducados de oro para llevárselos a la reina de Chipre en Rodas, donde se debía encontrar desprovista de recursos ${ }^{41}$. En agosto, Fiveller se había encargado de fletar una nave comercial, la de Jaume Coll i Vidal de Reixac, para efectuar el viaje y el rey le concedió la jurisdicción civil y criminal sobre los dos patrones, mercaderes y marineros y toda la gente que viajase en la nave, tanto durante el viaje de ida a Rodas y a Chipre como a la vuelta con la reina; todos tendrían que obedecerle como si fucra el mismo rey42. Fiveller también procuró aprovechar el viaje para resolver sus propios asuntos; una carta de Pedro el Ceremonioso al monarca chipriota recordaba a éste los servicios prestados por Fiveller tanto a su padre Pedro I como a él, entre los que destacó que había acompañado a su esposa Valentina Visconti a Chipre y lc pidió que le hiciera pagar los atrasos de las rentas de los feudos que le había concedido ${ }^{43}$. La nave salió el mismo mes de septiembre ${ }^{44}$, pero tanto la embajada cerca de la reina madre, para que le informase de todos sus asuntos, como la embajada en Chipre requirieron tiempo y el regreso no tuvo lugar hasta el año siguiente: probablemente, hubo que esperar

40. ACA. C. reg. 1268, fol. 74v,-75v. (1380, julio, 23). El cargo de Jean de Brie aparece mencionado normalmente como trichoperio.

41. ACA. C, cartas reales Pere III, no 1775 (1380, septiembre, 6).

42. ACA, C, reg. 1268, fol. 107v,-108r. (1380, agosto. 26).

43. ACA, C reg. 1268, fol. 103r. (1380, agosto, 23): cartas parecicas fueron enviadas a la reina de Chipre y a Jcan de Brie, turcopolier de Chipre: fol. 103v.

44. D. Coulon, Barcelone et le grand commerce d'Orient au Moyen Âge. In siècle de relations avec l'Égypte et la Syrie-Palestine (1330-1430 environ), tesis doctoral inédita dirigida por M. Balard, Universidad de la Sorbona, 1999, 3, p. 757. En prensa. 
que los mercaderes embarcados en esa nave terminaran sus negocios, puesto que quizás habían continuado viaje hacia Bcirut y Alejandría. La reina, pues, no llegó a Barcelona hasta el 28 de agosto de 1381 y entró en la ciudad al dia siguiente ${ }^{45}$. Había salido de su patria para casarse con una nave comercial y volvía del mismo modo, y no con una escolta de dos galeras como supone Hill, proyecto que, como he dicho, había sido abandonado ${ }^{46}$. El rey, que se encontraba en Zaragoza, manifestó su alegría por su llegada, aunque lamentó no haber estado presente, y prometió ocuparse de sus asuntos después de hablar con su padre ${ }^{47}$. El infante Pedro, que era entonces ya fraile franciscano, quería acudir a Roma junto al papa Urbano, de quien era partidario en la cuestión del Cisma, pero procuró ir antes a Barcelona para ver a su hija; el rey le pidió que pasara antes por Zaragoza ${ }^{48}$. El infante murió poco después, en Pisa, el 4 de noviembre de $1381^{49}$.

Parece que la embajada de Jaume Fiveller a Chipre para pedir explicaciones a la corte chipriota por la afrenta infligida a la reina Leonor logró inquictar al rey Pedro II, que mandó al Ceremonioso sus explicaciones y un proceso informativo para aclarar quien tenía la culpa de esa malvestat, como decía el monarca catalán; a juzgar por la respuesta de Pedro el Ceremonioso, el monarca chipriota, en un alarde de cinismo, había asegurado no tener responsabilidad ninguna en la expulsión de su madre y ser un buen hijo. El Ceremonioso aceptó esas explicaciones y le recomendó los asuntos de su madre y el batlliu que se encargaba de la administración de sus casales; le informó, además, de las gestiones que iba a emprender cerca de diversas autoridades, desde el común de Génova, al papa, el rey de Hungría y diversos señores italianos para que pudiera recuperar Famagusta; el rey agradeció también al auditor de Chipre, Jean Gorab (Gorap), a Tomás Arcofileta (Khartophylaka), que era el procurador de la reina, al confesor del rey de Chipre y al arzobispo de Nicosia su interés por los asuntos de la reina ${ }^{50}$.

\section{LA REINA EXILIADA DE SU REINO}

Una vez fuera de su reino, la primera preocupación de la reina fue el matrimonio de su hija Margarita, de la que había tenido que separarse. La reina, incluso antes de su llegada a Barcelona había enviado un mensajero al rey Pedro el Ceremonioso, Bordelet de Castellbó, para pedir su intercesión cerca de su hijo, el rey de Chipre, a fin de que permitiera el matrimonio de la princesa en les parts deçà, es decir, en los reinos de Pedro el Ceremonioso, con el objetivo evidente de tenerla cerca de ella y hacer menos dolorosa la separación de su familia. El monarca escribió, efectivamente, al rey de Chipre para pedirle que enviara a su hermana,

45. Crònica del racional de la ciutat, p. 155. La fecha que da esta crónica para la llegada de la reina es el 29 de agosto, fecha que no coincide con la indicada por el rey: 28 de agosto: suponemos que la reina llegó el 28 , pero que no hizo su entrada en la ciudad hasta el 29; de hecho la crónica habla de su cntrada en la ciudad.

46. Hıl., A History of Cyprus, 2, p. 426.

47. ACA, C. reg. 1276, fol, 40v,-4lr. (1381, septiembre, 8).

48. RuBió y LLLLCH, Documents per l'història de la culura, citado supra n. 14, 2, doc. 249, p. 343.

49. I?. BArUÉ, Notes sobre la reina Elionor de Xipre. des del seu retorn a Catalunya fins a la seva mort, Homenatge a Antoni Rubió i Lluch. Miscel.lània d'Estudis Literaris, Històrics i Lingüistics, Barcelona 1936, 3. p. 547-554, concretamente p. 549, n. 5 .

50. ACA, C, reg. 1274, fol. 73v.-74r. y 75r. (1382, junio, 8), publ. por MAs LATRIE, Histoire de l'lle de Chypre.3.p. 763-766. 
enjoyada como correspondía, puesto que él se encargaría de casarla de conformidad a su alto estamento; en todo caso le rogó que no la casara sin el consentimiento de su madre y de él mismo. Volvió a insistir sobre el mismo tema en 1382 y también rogó al papa Urbano VI que no concediera las dispensas para el matrimonio de la princesa Margarita, si era contra la voluntad de su madre ${ }^{51}$.

La otra preocupación de la reina y de sus parientes y amigos al instalarse en tierras catalanas fue la de los recursos con los que podría contar para vivir conforme a su estamento y dignidad. La dote de 42.000 besantes que la reina habia aportado había quedado asignada por concesión de su hijo, seguramente anterior a la ruptura entre ambos, sobre cuatro feudos o casales, de los que había de recibir las rentas, al menos en teoría porque en la realidad raramente la reina consiguió cobrar alguna cantidad; en 1392 Juan I hizo sellar con el sello real la copia de ese documento. seguramente en uno de los intentos para obtener el pago de aquellas rentas ${ }^{52}$. Conociendo esa situación, el rey Pedro el Ceremonioso se ocupó de asegurar a la rcina un mínimo que le permitiera subsistir, en cuanto llegó a Barcelona, cumpliendo así el compromiso asumido de tutelar a sus hijos cuando su tío el infante Pedro entró en la orden franciscana ${ }^{53}$. En primer lugar le concedió una pensión vitalicia de 2.000 florines de oro anuales sobre las rentas reales de la batllia de Xàtiva, con la salvedad de que, si volvía a Chipre o salía de sus reinos, dejaría de percibirla, como también la perdería si recibía sus rentas de Chipre como antes. También le dió, además, con carácter igualmente vitalicio, la villa de Valls - donde la reina pasó a residir -, con el mero y mixto imperio y con la jurisdicción sobre los donceles, es decir. los miembros de la baja nobleza. El mismo rey se interesó para que tanto el papa Urbano VI como Clemente VII, los dos papas enfrentados en el Cisma de Occidente, ayudaran a la reina ${ }^{54}$. En 1383, el rey se dirigió nuevamente a Urbano VI para que concediera una renta de 5.000 florines de oro anuales a la reina, que no tenía recursos, cediéndole además la parte de la jurisdicción de Valls que correspondía a la Iglesia de Tarragona ${ }^{55}$. En el disfrute de esas rentas no dejaron de presentarse dificultades, en Valls porque el batlle del paborde de Tarragona ocupaba rentas y derechos que pertenecían a la reina, mientras que había litigios territoriales con la vecina localidad de Vallmoll, que pertenecía al conde de Cardona; en el primer caso incluso se abrió una encuesta judicial ${ }^{56}$. También el cobro de las rentas de Xàtiva sufrió numerosos percances: otras asignaciones dejaban sin liquidez a los encargados de pagársela, o bien el batlle de Xàtiva demoraba el pago durante muchos días con los consiguientes gastos del procurador de la reina ${ }^{57}$.

51. ACA, C, reg. 1272, fol. 66r.-v. (1381, junio, 5); reg. 1276, fol, 136r.-v. (1382, diciembre, 26), reg. 1278, fol. 8 v., publ, por MAS LATRIE, Histoire de lille de Chypre, 3, p. 770-771.

52. ACA, C, reg, 1904, fol, 65v., publ, por MAS L AlTute, Histoire de l'ile de Chypre, 3, p. 778.

53. BaGUé, Notes sobre la reina Elionor de Xipre. cilado supra n. 49, p. 548, n. 3.

54. E. AYensa I Prat, Nuevos testimonios sobre la vida de Eleonor de Aragón, reina de Chipre (circa 1333 1416). Erytheia. Revista de Estudios Bizantinos y neogriegos 20. 1999. p. 153-171, concretamente, p. 155 156 y docs. 1-3, p. 159-160. en los que la reina Sibil,la apoya la petición hecha por su esposo al papa, al cardenal de Aragón (Pedro de Luna) y al maestre de la orden del Hospital, Juan Fernández de Heredia.

55. ACA, C, reg. 939, fol. 19r.-21v. y 23v.-26r., rcg. 1278, fol. 8r.; 976. fol. 189r., publ. por MAS LAIrIE, Histoire de l'ile de Chypre, 3, p. 761-763 y 767-769, 772-773. La donación de la renta sobre Xàtiva fue confirmada por el infante primogénito Juan: reg. 1768, fol. 74r.-76v. (1382, mayo, 17). De la jurisdicción de la reina sobre lus donceles de Valls, el rey excluyó a Bemat de Tamarit y a Ramon Sasallada y familias: reg. 850 , fol, 10v,-11r. (1386, octubre, 16).

56. ACA, C, reg. 1284, fol, 4r.-v. (1383, junio, 9), y fol, 10r.-v. (1383, juлio, 15), y 10v.-11r. y 13r.; reg. 1281, fol. 122r. (1383, septiembre, 26).

57. ACA, C, reg. 1281, fol. 155v. (1383, noviembre, 2); reg. 1109. fol. 65r. (1386, julio, 2). 
Al cabo de poco de haberse reinstalado en su patria, llegó la noticia de la muerte de su hijo, el rey Pedro II de Chipre, fallecido en plena juventud el 13 de octubre de 1382. Pedro el Ceremonioso supo la noticia vía Génova, cuando se encontraba en Tortosa, el 12 de enero de 1383; aunque era una noticia sin confirmar, cl monarca ordenó que fuera comunicada a la reina Leonor, por si había de tomar alguna medida, pues suponía que el reino podía afrontar una situación muy difícil58.

Pronto empezó la presión cerca del nuevo gobicrno para que resolviera las dos cuestiones que preocupaban a la reina: su hija y sus rentas. En mayo de 1383, el monarca volvió a insistir, ahora cerca del nuevo rey Jaime, sobre el matrimonio de la infanta; parece que por medio del caballero Alfons Ferran ya le había requerido, sin obtener respuesta, pero ahora que el monarca se aprestaba a hacerse cargo del gobierno de Chipre, volvió a solicitar que le enviase lá infanta, puesto que en Chipre no había marido adecuado para ella, mientras que él, actuando como padre, le buscaría uno in partibus cismarinis ${ }^{59}$. Finalmente la boda de la infanta Margarita parece que se resolvió a gusto de todos y Pedro el Ceremonioso aprobó, en mayo de 1386, la propuesta que le había llegado de Chipre en una carta del rey Jaime, traída por Francese de Casasaja; el marido propuesto fue el primo de Margarita, Jaime de Lusignan, conde de Trípoli. Nuevamente, Jaume Fivaller fue enviado a Chipre con este motivo y con el de interesarse por los casales, rentas y bienes del camarlengo del rey, Hug de Santa Paúb,

Por lo que respecta a los bienes de Leonor y de su hija, en enero de 1383 , Pedro el Ceremonioso ya se había preocupado de ello y había rogado a la hermana del nuevo rey, que según aquél se disponía a navegar hacia Sicilia, que velara por los bienes de la infanta Margarita, hermana del difunto rey, por los de su madre la reina Leonor y por los de sus súbditos, el noble Hug de Santa Pau, que era su camarlengo, Alfons Ferran, camarero, Jaume Fiveller, Lleó Marc y Francesc de Casasaja, que poseían rentas, casales u otros bienes por donación de los reyes de Chipre precedentes. Habían de llevar a cabo esa embajada Humbert de Fonollar y el mismo Alfons Ferran, que además de esa princesa habían de visitar también a Jean de Brie, turcopolier del reino de Chipre, a Jean Goras o Gorab (Gorap), auditor de Chipre; los embajadores habían de pasar también por Génova y presentar credenciales al dux $x^{61}$.

Pero no sólo no se solucionó el impago de las rentas de la reina sino que le fueron confiscados los casales y otros bienes por orden del batlle del rey, que quiso recuperar las pérdidas sufridas en el incendio de su casal de Tricomo por los genoveses, hecho del que, al parecer, culpaba a la reina. Pedro el Ceremonioso había recibido la embajada del rey Jaime de Chipre, confiada al caballero Alfons Ferran. En julio de ese mismo año, el rey mandó tres embajadores al monarca chipriota, el mismo Alfons Ferran, Hug de Santa Pau y Jaume Fiveller para rogarle que tratara fraternalmente a la reina y le devolviera sus bienes, teniendo en cuenta que a la muerte de ésta igualmente le revertirían, y que la reina necesitaba esos bienes para mantenerse ${ }^{62}$. Tampoco esa petición tuvo éxito puesto que al año siguiente hubo que protestar nuevamente por la ejecución judicial contrá los bienes de la

58. ACA, C, reg. 1281, fol. 61r.-v. (1383, enero, 12).

59. ACA, C, reg. 1282, fol. 51r.-v. (1383, mayo, 3$)$.

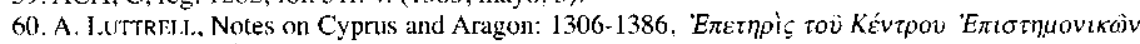

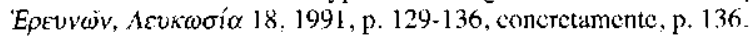

61. ACA, C, reg. 1281, fol. 77r.-v. (1383, enero, 23).

62. ACA, C, reg. 1282, fol. 101v.-102r. (1383, julio, 9). 
reina ordenada por Martino Bocaç, lombardo, que según la reina siempre se había mostrado parcial en su contra. Jaume Fiveller, que el rey había enviado a Chipre, como hemos visto, para resolver los asuntos de la reina, le había informado de todo ello a su vuelta. Así pues, el rey solicitó la ayuda del auditor de Chipre, Jcan Goras o Gorab, para proteger los bienes de la reina y de la infanta Margarita y amenazó veladamente con represalias; igual requerimiento fue dirigido a Jean de Brie y al gobierno del rey en Chipre63.

A pesar del contencioso entre ambas cortes por los bienes de la dote de la reina Leonor, el rey de Chipre solicitó galeras u otras naves a Pedro el Ceremonioso para ayudarle, en julio de 1384; el caballero Rainaldo Visconti se encargó de llevar a cabo esa embajada, que obtuvo una respuesta negativa, puesto que el rey alegó que todas sus fuerzas navales estaban comprometidas en la defensa de Cerdeña ${ }^{64}$.

Con el hijo y succsor del Cercmonioso, Juan I, continuaron los contactos frecuentes con la corte chipriota. En 1387, Juan I rogó a Jaime I de Lusignan que excusara al noble Hug de Santa Pau, que tenía que marchar a la isla para prestarle homenaje por su feudo, porque él no le permitía marchar ya que le necesitaba para su propia coronación. También le escribió, poco después, para pedirle que diera facilidades al mensajero del rey de Armenia, que éste enviaba a Chipre para obtener copia de una sentencia pronunciada en la corte chipriota, después de la muerte del rey Pedro, mientras gobernaba el príncipe de Antioquía, entre el mismo rey de Armenia y Juan Lascaris, caballero griego, marido de la suegra del dicho rey de Armenia 65 .

En 1389 las negociaciones para el pago de las rentas de la reina se habían iniciado de nuevo. Ahora, el encargado de llevarlas a cabo fue Francesc de Casasaja, un conocido patrón de nave y mercader barcelonés; es posible que ello sea indicio de enfermedad o muerte de Jaume Fiveller, que hasta entonces se había ocupado de todas las negociaciones referentes a la reina de Chipre. Pero la propuesta presentada por el rey de Chipre fue considerada inaceptable por Juan I, que exigió que se hiciera justicia a la reina y que se le pagaran sus rentas, puesto que se encontraba, decía, en la inopia. El mismo Casasaja había de volver a Chipre con esa respuesta66

Mientras sc resolvía esa cuestión, cl monarca solicitó de nucvo al papa, esta vez al de Aviñón, que concediera a la reina 2.000 florines de renta sobre ciertas iglesias del Camp de Tarragona y otros mil sobre las décimas de la misma comarca, puesto que se encontraba en la pobreza después de haber sido expulsada de su reino ignominiosamente y sin culpa suya: a regno predicto, in eisdem regine ignominiam et contemptum, absque culpa sua, expulsa extiterit indecenter. El rey había de ocuparse de su sustento como pariente suyo hasta el momento67. Esa concesión había de completar la efectuada en 1387 por el rey, que le había otorgado la parte que le correspondía por cesión papal en esas mismas décimas. Esa asignación real resultó después comprometida por la donación a la reina de todas esas décimas, por lo que la reina Violante tuvo que confirmar la validez de esa asignación a favor de la reina de Chipre, que algunos creían derogada por la donación posterior a su favor ${ }^{68}$.

63. ACA, C, reg.. (1384, octubre. 12).

64. ACA, C, reg. 1282, fol. 143v.-144r. (1384, julio, 11).

65. ACA, C, reg. 1867, ful. 2r--v. (1387, junio, 13), y reg. 1952, fol. 31v. (1387, agosio. 30).

66. ACA, C, reg. 1956, fol. 150r. (1389, agosto, 18).

67. ACA, C, reg. 1871, fol, 170r.-v. (1389, marzo, I6).

68. AYENSA I PRAT, Nuevos testimonios sobre la vida de Eleonor de Aragón, citado supra n. 54.p. 156 y docs. 4 y 5 . 
De nuevo Juan I insistió, en 1392, en la concesión de alguna ayuda a la reina por parte del papa, sugiriéndole que le otorgara algunas rentas de su cámara. Esta vez atribuyó la difícil situación de la reina a las guerras y a las revueltas de sus súbditos; por esta causa había tenido que retirarse a sus reinos, donde residía desde hacía más de doce años, viviendo de las rentas que le había asignado el rey Pedro el Ceremonioso ${ }^{69}$.

También en 1392 recomendó nuevamente al rey de Chipre los bienes de la reina Leonor y los de sus parientes y amigos ${ }^{70}$. En aquellos momentos, el rey intentaba un nuevo acercamiento a la casa real chipriota y había encargado una embajada a Francesc de Casasaja, que había de realizarla una vez hubiera llcgado a Sicilia la flota de su hermano, el infante Martín, duque de Montblanc, que había de restaurar en cl trono a la reina María de Sicilia, que se había casado con su hijo, Martín el Joven. Según el proyecto real, Francesc de Casasaja había de continuar viaje hacia Chipre con una de las galeras que la Diputació del General habŕa prestado al infante Martín. Pero Francesc de Casasaja todavía no había efectuado el viaje en abril de 1393, por lo que Juan I le reprendió. En su carta, el monarca aclaraba el motivo de la embajada: la propuesta de matrimonio de Jano, príncipe de Antioquía, con la infanta Isabel, hija del cuarto matrimonio del rey Pedro el Ceremonioso con Sibil.la de Fortià ${ }^{71}$. Probablemente, Francesc de Casasaja no había podido llevar a cabo el viaje a causa de las complicaciones que se habían presentado en la restauración de la reina María en Sicilia y de sus obligaciones como tesorero del reino, cargo para el que había sido nombrado por el infante ${ }^{72}$. Finalmente Ramon Fiveller, el hijo de Jaume, ya fallecido, y el vizconde de Roda, personas ambas que conocían Chipre, fueron quienes se encargaron de contactar con la corte chipriota por carta, para sugerir la posibilidad de ese matrimonio; después de haberse cruzado algunas cartas y asegurar que el rey Juan estaba interesado, el rey Jaime de Chipre envió dos cmbajadores, Juan Reamen y Juan de Castriguerio (Janot Castrigier), escudcro, quienes, junto con Ramon Fiveller, se encargaron de presentar al rey Juan I la carta del rey Jaime; el monarca chipriota consentía en continuar la negociación del matrimonio siempre que Juan I, en presencia de sus embajadores y del vizconde de Roda, Ramon de Perellós, se comprometiese a no tratar otro matrimonio para la infanta durante quince meses, mientras que los procuradores hubieron de hacer otro tanto con el procurador designado por el rey, Ramon Alemany de Cervelló 73 . Esa negociación matrimonial continuó con éxito y en mayo de 1396 Juan I escribía a Francesc de Casasaja que por carta del vizconde había sabido que los hombres del séquito de los embajadores del rey de Chipre, unos 120 hombres a caballo. habían entrado en Aviñón y que los embajadores, que venían a concluir la negociación del matrimonio, entrarían al día siguiente. El rey, pues, convocó a Casasaja, que entonces se encontraba en Cataluña, y a Ramon Alemany de Cervelló para que

69. $\Lambda$ CA, C, reg. 1963, fol. 34r,-v. (1392. febrero. 17). El rey encargó al cardenal de Valencia -el hermano de la reina- que presentara la carta y rogó al maestre de la orden del Hospital. Juan Fernández. de Heredia, que instara al papa en el mismo sentido.

70. ACA, C, reg. 1852, fol. 146v.-147r. (1392, agosto, 17).

71. ACA. C. reg. 1963, fol. 15v. (1392, enero, 18); reg. 1964, fol. $71 \mathrm{r}$-v. (1393, abril, 11),

72. P. CORRAo, Governare un regno. Potere, società e istituzioni in Sicilia fra Trecento e Quattrocento. Palermo 1991. p. 383-384.

73. Los procuradores llevaban una procuración a favor del vizconde para que recibiera el compromiso de Juan I en nombre del rey de Chipre, aunque el vizconde no estaba presente en aquel momento en la corte y se supone que hubo de proceder más tarde a tomar ese juramento: ACA , C, reg. 2012, fol. 34r. -35v. (1394, noviembre, 2). La carta del rey Jaime, que se incluye, era del 15 de enero de 1394. 
acudieran a la corte para asistir al acto de la firma del compromiso ${ }^{74}$. Pero sólo cinco días más tarde, Juan I moría de repente mientras cazaba ${ }^{75}$. El matrimonio no llegó a acordarse ni siquiera sabemos si los embajadores chipriotas llegaron a Barcelona. El momento, de gran tensión por las amenazas de entrada de compañías extranjeras con el objetivo de saquear el país, no era propicio para esta clase de negociaciones matrimoniales. El nuevo rey, el infante Martín, hermano de Juan I, estaba ausente en Sicilia y antes de que pudicra volver hubo que afrontar una invasión del conde de Foix, que también aspiraba al trono en nombre de su esposa la infanta Juana, hija de Juan I. Las negociaciones pues, quedaron interrumpidas. En 1400, sin embargo, el rey Martín el Humano se interesó por otros matrimonios, el de las hijas de la princesa Margarita, hija de Leonor, con los hermanos del rey Jano y se ofreció a casarlas en sus reinos si el monarca chipriota no aceptaba esa propuesta $^{76}$.

Las noticias sobre las relaciones con Chipre y sobre las constantes reclamaciones de sus rentas son también numerosas durante el reinado de Martín el Humano, pero no las consideraré ahora para no alargarme en exceso.

La reina Leonor llevó una vida retirada en su castillo de Valls. Sólo conocemos un posible desplazamiento, en noviembre de 1384, para huir de la epidemia que se había declarado en el lugar. El rey la recomendó a todos sus oficiales para que, allí donde se dirigiera, la asistieran en todo lo que necesitara ${ }^{77}$. En 1386, el monarca le concedió la jurisdicción sobre todos los hombres de paratge de su casa, es decir a los de estirpe noble, aunque de los estamentos inferiores de la nobleza ${ }^{78}$. Sus relaciones con la villa de Valls no fueron buenas por causa de su negativa inicial a pagar algunos impuestos y por causa de tensiones entre sus domésticos y la gente del lugar. Como señala Eusebi Ayensa, se produjo un grave incidente en 1394, cuando vecinos de Valls irrumpicron violentamente en el palacio de la reina, mataron a su escribano de ración y robaron joyas y otros bienes suyos; seguramente ese grave incidente indujo a la reina a trasladar su residencia a Barcelona, donde residió hasta su muerte, acaccida el 26 de diciembre de $1416^{79}$. Su extraordinaria longevidad la privó primero de su hijo y de su hija ${ }^{80}$, de sus hermanos y poco a poco de la mayor parte de sus domésticos; también la precedieron en la muerte cuatro reyes de la Corona de Aragón y numerosas reinas. Como señaló Agustí Duran, la reina vivió en una atmósfera de luto obsesivo en su casa de Barcelona, situada en la calle Mercaders ${ }^{81}$, mientras que los cronistas franciscanos alaban su piedad y su actuación caritativa ${ }^{82}$.

74. ACA, C. reg. 1967, fol. 125v.-126r. (1396, mayo, 13).

75. Mannal de novells ardits, vulgarment apellat Dietari del Antich Consell Barceloní. I. Anys I3901446, ed. F. SCHWARTZ y LunA, F. CARRERAS y CA.NDi, Barcelona 1892, p. 57.

76. ACA, C, reg. 2243, fol. 151v.-152r. (1400, noviembre. 10). Se conservan otras carlas sobre estas propuestas.

77. ACA, C, reg. 844, ffol. 61v.-62r. (1384, novicmbre, 30).

78. ACA, C, reg. 948, fol. 102v.-103r. (1386, noviembre, 6), publ. por MAS I ATRIE, 3, p. 773-774.

79. AyenSA I PRAT, Nuevos testimonios sobre la vida de Eleonor de Aragón, p. 156-159 y doc. 6.

80. ACA, C, reg. 2184, fol. 36v,-37r. (1408, marzo, 14). Jil rey Martín el Humano se refería a una carta anterior escrita al rey Jano en la que le daba la condolencia por la muerte de la condesa de Trípoli y le recomendaba a sus hijos.

81. A. DuRan I Sanl'ERe, Elionor d'Aragó, reina de Xipre, Barcelona i la seva historia. II, La seciefat il'organirzació del treball. Barcelına 1973, p. 592-595. Fl inventario de la casa, redactado a su muerte, indica la presencia de numerosas cortinas negras en dos comedores, dosel negro en la cama, silla de la reina forrada de negro, vestidos negros etc.

82. Ibid., p. 592. Cf. también A. E. Sol., À, La tïn pieuse d’une reine impie, XIIT Colloque International 


\section{ALGLNOS CATALANES DEL ENTORNO DE LA REINA LEONOR}

Alfons Ferran o Ferràndez. Era caballero y era uno de los servidores de la reina Leonor de Chipre que aparecen a su lado desde 1373 como mínimo, aunque probablemente su presencia en Chipre era anterior, puesto que en alguna ocasión se dice que era un servidor de la casa de Chipre desde antiguo ${ }^{83}$. En 1373 era tesorero de la reina Leonor y viajó hasta Barcelona y otros lugares no especificados, seguramente para resolver asuntos de la reina. El rey Pedro el Ceremonioso le recibió entonces como a familiar y doméstico suyo; consta que era súbdito de Pedro el Ceremonioso ${ }^{84}$. No he podido aclarar el nombre exacto de este Alfons Ferran. Una carta en latín de 1378 , dirigida a la reina de Chipre, le cita como Alfonsus Ferran, mientras que otra carta en catalán, del 1383, le cita como mossèn Alfonso Ferràndez, lo que hace dudar de su lugar de origen; si el nombre es Ferràndez no puede ser catalán, podría ser de origen aragonés, residente en Cataluña o Valencia ${ }^{85}$. Ya hemos visto que fue enviado a Cataluña por la reina de Chipre, en 1378, para buscar gente de armas que quisiese pasar a la isla tomando su sueldo, para recuperar Famagusta, aunque no llevaba dinero suficiente y acabó en la cárcel. En 1382 llevó a cabo otra cmbajada a Pedro el Ceremonioso de parte de Jaime de Lusignan, condestable de Jerusalén y Chipre y tío del rey de Chipre, que se encontraba prisionero de los genoveses y deseaba la mediación del rey para que su sobrino le enviara dinero de sus rentas en Chipre para socorrerle, mediación que el rey llevó a cabo mandando al rey de Chipre al mismo Alfons Ferran con una carta ${ }^{86}$. Un hijo de este Alfonso Ferran o Ferràndez, llamado Juan, cra en 1384 y 1385 patrón de una galera llamada Sant Cebrià que cooperó durante un cierto tiempo en la defensa de los mares de Curdeña con Arnau Aymar ${ }^{87}$. Algunos documentos que hacen referencia a las capturas que ambos realizaron le llaman Juan Alfonso, por el nombre de su padre, pero el recibo de un pago de cien ducados de oro electuados en su nombre por Jaume Fiveller a un canónigo de la catedral de Barcelona nos permite aclarar la filiación de ese Juan Ferrandi y su paso por Càller (Cagliari), donde el patrón catalán Mateu Gelat confesó deberle, en julio de 1384,500 ducados $^{88}$. No había otros navíos chipriotas navegando por esa zona, de manera que la identificación parece clara.

Jaume Fiveller. Pertenecía a una de las familias de la oligarquía barcelonesa que, desde fines del siglo XIII a principios del siglo XIV, se había dedicado a la banca ${ }^{89}$, aunque después parece haber entrado en el grupo de los ciutadans honrats, que no se dedicaban a ninguna profesión concreta sino que vivían de sus rentas y ocupaban

des Néo-hellénistes des Universités Francophones. La langue, la littérature, l'histoire et la civilisation chypriotes (Université de Nancy II, 13-15 mai 1993), Besançon 1995, p. 222-232, que no he podido consultar.

83. ACA, C. reg. 1285, fol. 185r.-v. (1384, octubre, 12).

84. ACA, C. reg. 924, fol. 200r-v. (1373, septiembre, 27).

85. ACA. C, reg. 1261, fol. 70r. (1378, abril, 1); reg. 1281, fol.77r. (1383, enero, 23).

86. ACA, C, reg. 1281, fol. 20r.-v. (1382, noviembre, 28).

87. P. SimblLA, Corsari e pirati nei mari della Sardegna, Cagliari 1993, p. 184 y 187-189 y doc. II D, p. 324 y 331. M. T. Ferker 1 MAI.I.ol., Arnau Aymar, capità i corsari de Mallorca (segles XIV-XV), Randa 51, 2003. Homenatge a Miquel Batllori, 4, p. 63-64.

88. AHPB, 36-11 (Antoni Bellver, libre comí), fol. 31v,-32r. (1385, octubre, 12).

89. St. P. BENSCH. Barcelona i els seus dirigents 1096-1291. Barcelona 2000, p. 269 y 306 (Traducción de Barcelona and its rulers, 1096-/29/, Cambrige 1995). 
cargos en la ciudad o junto al rey. Jaume Fiveller murió en 1390 o poco antes; su testamento, desgraciadamente, no se ha conservado, por lo que ignoramos aspectos concretos de su familia; sólo se conoce el nombre de su esposa, que se llamaba Constança, el de su hijo y heredero Ramon y el de una hija llamada Sança, que se casó con un mercader barcelonés llamado Bernat Pol, que también estuvo al servicio de la reina Leonor de Chipre ${ }^{90}$. Está documentada su presencia en la ceremonia religiosa de la traslación del cuerpo de Santa Eulalia a su nuevo sepulcro de mármol en la catedral de Barcelona en $1339^{91}$, mientras que en 1356 debió participar en alguna bandería ciudadana porque el procurador general de Cataluña, Pere de Montcada, ordenó su confinamiento domiciliario, igual que el de Ramon y Joan Marquet, Guillem de Lacera y Macià Messeguer ${ }^{92}$. En los años siguientes se dedicó activamente a la política municipal y a la general, puesto que fue conseller quinto de Barcelona en 1359, cuarto en 1362 y segundo en 1366 y participó también en el organismo que había nacido quince años antes, la Diputació del General de Cataluña o Generalitat, como diputado del brazo real, entre 1375 y $1376^{93}$.

Ya he señalado su embajada a Chipre en 1369 para expresar, de parte del rey Pedro el Ceremonioso, su condolencia a la reina Lconor de Chipre después del asesinato de su esposo. Sin embargo ese no había sido su primer contacto con la corte chipriota. Pedro I, el esposo de la reina Leonor, le había concedido una renta de mil besantes anuales sobre el impuesto del comercio de Famagusta, renta que le fue confirmada por Pedro II. Esta concesión supone una estancia anterior al 1369, año de la muerte de Pedro I, en la isla y algún servicio prestado a los reyes. La ocupación de Famagusta por los genoveses debió dejarle sin esa renta, por lo que unos dicz, años después, en enero de 1383, el rey Pedrel Ceremonioso rogó a los genoveses que se la devolvieran ${ }^{94}$.

En 1378, junto con Lleó Marc. miembro de una familia con la que mantuvo estrecha relación ${ }^{95}$, se ocupó de armar cinco galeras para acompañar a Valentina Visconti, hija del señor de Milán, a Chipre, con motivo de su matrimonio con el rey Pedro de Chipre, hijo de Leonor, como hemos visto. Cada uno de ellos aceptó, en 1379 , un donativo de la reina de 1000 ducados de oro por los servicios prestados y por los gastos sostenidos en el viaje que realizaron a Chipre para acompañar a Valentina Visconti, con la pequeña flota que finalmente fue de seis galeras, bajo la capitanía del noble Hug de Santa Pau96.

Supongo que fue en esa ocasión cuando tanto Jaume Fiveller, como Lleó Marc, como el mismo Hug de Santa Pau, recibieron bienes en Chipre. Por esta razón Jaume Fiveller tuvo desde entonces un factor o representante en la isla. A causa de

90. AHPB, 55-13 (Ponç Amorós, Secundus liber procuracionum), fol. 23r.-24v, y 126v.-128r. (1390, julio, 6). Sobre la dote de su hija Sança, de 20.000 sueldos, de la que formaba parte una casa que compró para ellos: AHPB, 32-1 (Pere Bajaguer. Llibre comú), fol. 40v. (1379, agosto, 28).

91. S. Pug y Puic, Episcopologio de la sede barcinonense, Barcelona 1929, p. 248.

92. Arxiu de la Catedral de Barcelona, Notaris, manual 250 (Francesc de Ladernosa), fol. 13v. (13.56, agosto, 25).

93. M. T. Ferrlir I MALLOL, 1375-1376. Romeu Sescomes, Història de la (Feneralitat de Catalunya i dels seus presidents, dir. J. M. Sol I. I SABATÉ, 3 vol., Barcelona 2003, 1, p. 71-75.

94. Mfioni, Genova e Aragona, 3, p. 153, n. 45.

95. También tuvo mucha amistad con el padre de 1.lcó, Jaume Marc, caballero, de quien fue nombrado albacea en su testamento de 1360: es posible que tuvieran algún lazo de parentesco, aunque de momento lo desconocemos. Cf. el testamento de Jaume Marc en: J. MAKCH, Obra poètica, ed. J. Pujol, Barcelona 1994, p. 259 (Els nostres Clàssics, col. A, 133).

96. AHPB, 23-4 (Francesc de ladernosa, manual 14), fol 47v-48r. (1379, diciembre, 13). 
la muerte de ese factor, en 1387, el rey Pedro el Ceremonioso recomendó al rey de Chipre al patrón barcelonés Joan Pujada, que fue enviado a la isla por Jaume Fiveller para recuperar los bienes, mercancías y rentas que le pertenecían y que se encontraban en poder del factor, Domingo de la Fos; también le recomendó a Pierre de Cafran, almirante del reino, y a Tomás Arcofileta (Khartophylaka), procurador del monarca chipriota; según otra carta de recomendación de los consellers de Barcelona para el mismo asunto, los procuradores enviados fucron dos, también Jaume Coll, además de Joan Pujada ${ }^{97}$. Después de la muerte de Jaume Fiveller, su hijo Ramon, en nombre propio y de su madre, Constança, envió a Chipre, en 1390, tres procuradores, Ramon de Blanes de les Escales, doncel, Guerau de Palou y Pere Bertran, ciudadanos de Barcelona, para reclamar bienes que se le debían, comandas etc..$^{98}$.

En 1379 consta que tanto él mismo como Lleó Marc eran procuradores de la reina; quizás por esta causa y por su conocimiento de la corte de Chipre, los parientes y amigos de la reina le rogaron que viajara a la isla con el fin de obtener su liberación, ya que se decía que su hijo la tenía presa en un castillo. En 1380 fuc efectivamente enviado a Chipre para protestar ante el rey Pedro II por su mal comportamiento con su madre y para devolver a la reina a su patria de origen, como ya hemos visto. En las cartas sobre este asunto, Jaume Fiveller es citado, al menos desde 1382, como consejero del rey Pedro el Ceremonioso ${ }^{99}$. En ese mismo año fue síndico de Barcelona en las Cortes de Monzón ${ }^{100}$, pero en 1383 tuvo que realizar un nuevo viaje a Chipre, del que había vuelto poco antes del mes de octubre de 1384 , siempre por asuntos de la reina, de los que después informaba al rey Pedro el Ceremonioso ${ }^{10 !}$.

En 1386, el rey Pedro el Ceremonioso le confió una embajada importante al sultán de Babilonia. El sultán, solidarizándose con el de Túnez, había mandado a la corte de Pedro el Ceremonioso una protesta muy enérgica a causa del ataque perpetrado por Guillem Ramon de Montcada contra dos galeras cargadas de mercancías de Túnez. El embajador había de hacer notar que había hostilidades entre la Corona de Aragón y Túnez i que, por tanto, las capturas corsarias no cran ilegales; por otra parte, había de destacar que el autor era un miembro de la rama siciliana de esta gran familia noble catalana y que, si bien era de origen catalán por sus antepasados, cra súbdito del rey de Sicilia. El rey había previsto que también participasen en las negociaciones tanto el cónsul en Alejandría, Bernat de Gualbes, como Bernat Pol, de la ciudad de Barcelona. Habían de confirmar la paz

97. ACA , C, reg. 1827, fol. 152v.-153v. (1387, junio, 5). En esta ocasión, el nombre de Fiveller aparece cambiado en Civeller; el significado es el mismo, pues ambos nombres designan al fabricante de hebillas, de modo que el error es comprensible. El nombre aparece correctamente en otra carta de recomendación enviada por los consellers de Barcelona al mismo rey de Chipre el 13 de junio de $1387: A$. DF Capmany y de MontPalau, Memorias Históricas sobre la Marina, Comercio y Artes de la Ciudad de Barcelona, recdición anotada y revisada por E. GIRAit y RaVfentós, C. Bati.te y Gall.aki, 2, Barcelona 1962, doc. 233, p. 340-341. Ct. también P. Voltes, V. VLlacAmpa, Repertorio de documentos referentes a los cónsules de Ultramar y al consulado de Mar conservados en el Instituto Municipal de Historia de Barcelona, en Aportacione's a la Historia Económica y Social de la ciudad. Barcelona 1964, p. 33 (Documentos y Estudios 13).

98. AHPB, 55-13 (Ponç Amorós. Secutudus liber procurationum), fol. 23r.-24v. (1390, julio, 6).

99. MAS LATRIE, Histoire de l'île de Chypre. 3 , p. 76.5.

100. Joan Francesc Boscà, Memorial Històric, ed. J. Sobrequts r Callicó, Barcelona 1977, p. 119.

101. ACA, C, reg. 1285, fol. 185r.-v. (1384, octubre, 12). Ya citado antes. 
existente y habían de insistir en la tesis de que los mercaderes habían de ser tratados como a mercaderes y los corsarios como a corsarios, porque había la costumbre de hacer pagar a los mercaderes todos los incidentes que se producían ${ }^{102}$.

Lleó Marc. Era patrón de nave y pertenecía a una familia barcelonesa ennoblecida, aunque él permaneció en el estamento mercantil. Estuvo casado con Violant Sentbreç y tuvo dos hijos, Jaume y Arnau, y una hija, Constança; murió después de 1409. Su abuelo, Pere Marc, había asegurado la fortuna de la familia gracias a los servicios prestados al rey; había ocupado los cargos de escribano, escribano de ración y después tesorero de Jaime Il, maestro racional, equivalente a ministro de hacienda, del rey Alfonso el Benigno, hijo del anterior y había sido conscjero de ambos reyes; había comprado el castillo de Eramprunyà, cerca de Barcelona. con un señorío bastante extenso y diversas posesiones en Valencia, lo que más adelante facilitó el acceso a la caballería de su hijo Jaume, que fue armado caballero a los 60 años, como tambićn, lo fueron, algo más tarde, dos de sus hijos, ambos poetas, Jaumc y Perc, cste último padre del gran poeta Ausiàs March o Marc; estos dos hermanos habían combatido en la guerra contra Castilla ${ }^{103}$, lo que explica su acceso a la caballería, mientras que su hermano Lleó no parece haberse interesado ni por la poesía ni por la guerra terrestre, aunque sí practicó la guerra en corso; en 1359, durante la guerra contra Castilla recibió, como otros armadores, una ayuda de la Corona, para armar conjuntamente con Berenguer Carreres, también de Barcelona, contra Castilla, Portugal y el reino nazarí de Granada; tenemos noticia, sin embargo, de que realizaron un apresamiento de cautivos en Alcudia, en el Magreb. Parece que continuaron en esa actividad al menos hasta $1361^{104}$. Esa dedicación al corso fue motivada por la guerra; antes y después se dedicó pacíficamente al comercio y al transporte marítimo. Amada López de Meneses afirmó, sin indicar la fuente, que a fines del 1336 actuaba ya como mercader, aunque debía ser muy joven, y que en 1353 figuraba entre los que compraron géneros en la nave traída de Romania por Ponç de Santa Pau, tomada en el curso de la guerra con Génova. Posteriormente, se dedicó al transporte hacia el Oriente mediterránco; en 1365, Lleó Marc llevó la coca Santa Eulàlia a Alejandría, junto con Ramon de Màrgens y Bernat de Tordera y, aunque llegó a ese puerto después del ataque de Pedro I de Chipre, resultó igualmente represaliado ${ }^{105}$. Es, seguramente, a consecuencia de esta pérdida que mantuvo pleitos con los mercaderes de la nave para repartir lo que se había podido sacar de Alejandría. La noticia sobre una sentencia de los cónsules del mar y de otra sentencia de apelación al rey, que le fue favorable, no permite comprender qué había pasado; aunque su calificación de expatrón de nave indica que la pérdida había sido graveio6.

102. A. Lópfz. de Menesfs, Los consulados catalanes de Alejandría y Damasco en el reinado de Pedro el Ceremonioso, Estudios de Edad Media de la Corona de Aragón 6, 1956, docs. 29-32, p. 165-168. 103. Sobre la familia de Lleó Marc cf. Pere MARCH, Obra completa, ed. Lluís CABré, Barcclona 1993, p. 13-15, 17 y 18 (Els Nostres Clàssics, 132. col. A). J. MARCH, Obra poètica. citado supra n. 95, p. 15 , p. 18 y especialmente el cuadro genealógico al final de la obra.

104. M. D. López PÉrez, La Corona de Aragón y el Magreb en el siglo XIV (1331-1410), Barcelona 1995, p. 589. ACB, Notarials 228 (Pere Borrell), fol. 83v.-84r. (1360), mayo, 20), cf. tambićn algunas reclamaciones del salario debido por parte de gente que había servido en su galiota: fol. $128 \mathrm{v}$. y $132 \mathrm{v}$. 105. LOPEZ DF MENESES, L Los consulados catalanes de Alejandría y Damasco, citado supra n. 102, p. 100. 106. ACA, C, reg. 735 , fol. 103v,-104v. (1367, diciembre, 18). 
En Valencia, su hermano Jaume Marc había sido procurador de Alfonso, conde de Denia y marqués de Villena, uno de los hermanos de la reina Leonor de Chipre; el otro hermano, Pere, había caído prisionero de los ingleses, como el mismo conde de Denia, en la batalla de Nájera, en 1367, donde fue derrotado Enrique de Trastámara y también hubo que rescatarle. Esa vinculación familiar explica la estrecha relación de Lleó con la reina de Chipre ${ }^{107}$. Aparece por primera vez en relación con clla, según la documentación que tenemos por ahora, en el viaje de vuelta de Chipre de 1372, en el que trajo regalos de la reina Leonor para la esposa de Pedro el Ceremonioso, como ya hemos indicado. Desde entonces aparece con frecuencia llevando cartas y regalos entre Chipre y la corte catalana, como en 1374 , en que consta que volvió de Chipre. En 1377, como procurador de la reina de Chipre y junto a Joan Desbosc, se ocupó de reclutar gente de armas en Cataluña para luchar contra los genoveses en Chipre; para pagar los anticipos había recibido dinero y mercancías en Chipre, probablemente azúcar, como ya he dicho. En fecha que desconocemos, pero quizá en relación con sus servicios para buscar socorro militar entre 1377 y 1378 , recibió posesiones en Chipre, por las que el rey Pedro el Ceremonioso se preocupaba en 1383, como por las de los demás súbditos suyos que también tenían. En 1385, el infante primogénito Juan le pidió el libro de Godefroy de Bouillon, que había pertenecido al rey de Chipre y que Lleó Marc tenía, quizás por donación del mismo rey o de la reinalo8.

Francesc de Casasaja. Pertenecía a una familia que comenzó a significarse con él mismo. Tenía un hermano, Pere, que se distinguió mucho en el comercio con Oriente y otro hermano, Jaume. Se casó en primeras nupcias con Joana Massot y en segundas con Constança Llopart. Tuvo un hijo, Francesc, que fue el heredero, y cuatro hijas, Joana, Isabel, Elionor y Caterina. Murió en Sicilia, en Caltagirone, el 11 de diciembre de $1406^{109}$. Se dedicó desde 1360 , aproximadamente, al transporte comercial hacia el Oriente: Chipre, Beirut y Alcjandría. Sus viajes fueron numerosos. Damien Coulon ha documentado al menos doce entre 1369 y 1390 , lo que demuestra una gran regularidad. El mismo autor supone que debió transportar mercancías propias, a fin de completar las ganancias derivadas de los fletes, pues de otro modo no se explicaría su enriquecimientollo. Hay constancia de que en algún momento frecuentó también la ruta del norte de África, por ejemplo en 1366 realizó un viaje a Túnez'11. Se mostró poco inclinado a la política municipal barcelonesa. Sólo cuando, en 1386, el rey Pedro el Ceremonioso forzó una reforma democratizadora del gobierno de la ciudad, participó en una comisión asesora de los consellers, formada por doce miembros, en la que los ciudadanos quedaron en minoría112. Se desconoce, por el momento, cuándo comenzó a relacionarse con la reina de Chipre, pero debió ser pronto, ya que cra uno de los patrones que tocaban

J07. Cf. lá nota 103.

108. RuBıó y Li.uch, Documents per l'història de la cultura, l, doc. 368, p. 331.

109. AHPB, 58-174 (Bernat Nadal, Llibre de testaments), fol. 73r. (publicación del testamento) el testamento propiamente dicho, redactado el 5 de agosto de 1406, se cncuentra en los folios 69r.-72v. C.f. cl arbol genealógico que presenta Courov, Barcelone et le grand commerce, citado supra n. 44, 3 , p. 627 .

110. Ibid., p. 623-624.

111. Lope7. PÉktz, La Corona de Aragón y el Magreb, citado supra n. 104, p. 175. n. 15.

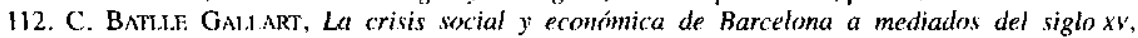
Barcelona 1973, p. 94. 
regularmente en la isla y que, por tanto, podían llevar cartas, regalos etc. entre ambas cortes. En 1378, como ya he comentado, ayudó en la preparación de la flota destinada a acompañar a Valentina Visconti hasta Chipre adelantando dinero para la expedición. Debió ser entonces cuando sus servicios fueron recompensados con los feudos de Presterona (Peristerona) y Corinia, por los que en 1402 había de prestar juramento de fidelidad y homenaje personalmente al monarca chipriota, aunque el rey Martín el Humano solicitó que pudicra hacerlo por medio de procurador, ya que él le necesitaba a su servicio ${ }^{113}$. En sus viajes, frecuentemente llevó regalos o cartas, por cjemplo en 1383 o en 1386, casos que ya he comentado. En 1389 fue enviado a negociar con el rey de Chipre el pago de las rentas a la reina Leonor; pero tuvo que efectuar un nuevo viaje porque Juan I no aceptó la propuesta del monarca chipriota. En 1392, el rey Juan I le encargó que realizara una embajada en Chipre para proponer el matrimonio de la infanta Isabel, hermana del rey, con el príncipe heredero, Jano; como ya he dicho, había de dirigirse a Chipre una vez hubiera llegado a Sicilia la flota del infante Martín, peno Casasaja no efectuó finalmente ese viaje, a causa de las complicaciones que se habían presentado en la restauración de la reina María en Sicilia y de sus responsabilidades en el reino, en donde desempeñó el cargo de tesorero entre 1392 y 1395114 . Sus contactos con la corte catalana para presentar cartas o regalos de la corte chipriota dieron paso a un trato frecuente con los reyes de la Corona catalano-aragonesa que le encargaban artículos orientales. Fuc, sin embargo con el infante Martín, que sucedió a su hermano Juan I, con quien los lazos de amistad fueron más fuertes. Francesc de Casasaja fue uno de los consejeros, sin cargo curial, más notables del infante y después rey; su ayuda fue preciosa para adelantar dinero con el que pagar gastos de la preparación de la flota que llevó al infante a Sicilia o para preparar una expedición de socorro a la isla, con Bernat de Cabrera, sn 1397; se ocupó de la financiación del envío de más socorros al rey Martín el Joven en 1398 y se encargó de llevar personalmente a la isla una ordenación del gobierno de Sicilia redactada por el rey Martín el Humano, que no estaba satisfecho de cómo funcionaba el gobierno siciliano presidido por su hijo, joven y con poca experiencia. Para premiar sus servicios, Martín el Humano le había concedido, ya en 1392, la tonnara y el castillo de Solanto, situado cerca de Palermo 115. En 1402 llevó a cabo una embajada a Bona, junto al noble Pere de Queralt, para obtener la liberación de los cautivos catalanes y, al menos habían de procurar obtener la de Berenguer de Laccra, vicecomprador del rey Juan I, apresado nueve años antes, cuando iba de Valencia a Barcelona en servicio del reyl16. Al año siguicnte, el rey Martín el Humano le encargaba un asunto familiar: que fuese a buscar a Sicilia a sus nietos, hijos naturales de su primogénito Martín el Joven, rey de Sicilia; se trataba de Federico, conocido después como Federico de Luna, que fue uno de los aspirantes a la corona a la muerte de Martín el Humano, y Violante. En julio de 1404 Casasaja ya había traído los niños a Barcelona, con gran alegría de su abuelo, que les proporcionó una educación esmerada ${ }^{17}$. El ataque de corsarios berberiscos contra Solanto, su feudo en Sicilia, en julio de 1406, en un año de

113. ACA, C, reg. 2175, fol. 73r. (1402, marzo, 13).

114. CoRRAo, Governare un regno, citado supra n. 72, p. 383-384.

115. Ibid., p. 539.

116. M. T. Fterker I MALLUL, La redempció de captius a la Corona catalano-aragonesa (segle XIV), Anuario de Fstudios Medievales 15, 1985, p. 237-297. concretamente. p. 251.

117. R. TAsis I MARCA. Pere el Cerimoniós $i$ els seus fills. Barcelona 1962, p. 211 y 213. 
grandes armamentos marítimos contra cristianos en los territorios hafsíes, le obligó a acudir a Sicilia, seguramente para examinar la situación en su señorío y tomar medidas de defensa. Había programado partir con la nave de Pere Pellicer en agosto del mismo año ${ }^{118}$. Así debió hacerlo, pero de ese viaje ya no volvió y encontró la muerte en Sicilia, en diciembre de 1406.

De las muchas personas que tuvieron relación con la reina de Chipre he escogido, para hacer su semblanza, a las que disfrutaron de feudos y rentas en la isla. De algunos de ellos, particularmente de Jaume Fiveller y de Francesc de Casasaja se podría escribir más, pero lo que he apuntado es suficiente para tener una idea de las personas que le sirvieron de enlace con su país de origen. De los demás, otros miembros de la familia Casasaja, numerosos procuradores, domésticos chipriotas y domésticos catalanes me ocupo en otro estudio sobre la pequeña corte de la reina en el exilio ${ }^{119}$.

Maria Teresa Ferrer i Mallol CSIC. Institución Milá y Fontanals 